Article

\title{
Green Credit and Company R\&D Level: Empirical Research Based on Threshold Effects
}

\author{
Huiying Chen, Chuanzhe Liu *, Fangming Xie, Tong Zhang and Fangyuan Guan \\ School of Management, China University of Mining \& Technology, Xuzhou 221116, China; \\ chy651201@163.com (H.C.); m15246349728@163.com (F.X.); 13159776551@163.com (T.Z.); \\ bdmkgfy@163.com (F.G.) \\ * Correspondence: rdean@cumt.edu.cn; Tel.: +86-0516-8359-0168
}

Received: 28 February 2019; Accepted: 25 March 2019; Published: 30 March 2019

\begin{abstract}
Commercial banks follow sustainable development strategies to provide green credit for companies. As the main target for banks to issue green credit, environmental protection companies carry out research and development (R\&D) activities for the purposes of protecting the environment and sustainable development. Therefore, the R\&D level of environmental protection companies is a measure of whether the green credit policy meets its purpose. Therefore, it is particularly important to study green credit from a company perspective. This paper used panel data from 24 environmental protection companies listed on the Shanghai and Shenzhen Stock Exchange from 2012 to 2017 and adopted a threshold model to examine the relationship between green credit and company R\&D level. The results indicate that there is a positive but nonlinear relationship between green credit and company R\&D levels. The empirical analysis through the threshold model shows that a threshold effect remains on the relationship and this threshold effect is caused by the levels of firm size, bank lending, and government subsidies.
\end{abstract}

Keywords: green credit; environmental production companies; R\&D level; threshold effect

\section{Introduction}

With the rapid development of the global economy, environmental issues have become increasingly prominent, and the green economy has gradually become a focus of attention. In 2003, ten influential banks, including Citibank and ABN-AMRO Bank, developed and implemented the Equator Principles (EPs). EPs use the World Bank's environmental protection standards and the IFC's social responsibility policy to assess and manage finance in relation to environmental protection, social responsibility, and other related projects. Green finance affects the investment orientation of enterprises and provides corresponding financial support for the development of green industries. It also promotes the ecologicalization of traditional industries and development of new green ecological industries.

The green credit policy has dominated China's green finance development model. Since 2007, the Chinese government has exerted tremendous effort to promote green credit. Aizawa and Yang (2010) [1] proposed that China has implemented a series of green policies (such as green taxation, procurement, and credit), of which the green credit policy is the most advanced. In 2016, China advocated the establishment of the G20 Green Finance Research Group to investigate how the world develops green finance and how to improve the greening of global financial institutions. Presently, the Chinese government and financial institutions are paying increasing attention to environmental issues. They proposed a series of incentive measures to support and encourage green investment and green finance.

Figures 1 and 2 depict China's five largest state-owned commercial banks (SOCBs), namely, China Construction Bank (CCB), Agricultural Bank of China (ABC), Bank of China (BOC), Industrial and 
Commercial Bank of China (ICBC), and Bank of Communications (BCM) 2013-2017 green credit balance and green credit ratio. The figures show that the proportion of green credit balance and ratio has been increasing yearly. Among them, $\mathrm{CCB}^{\prime}$ s green credit balance is at the top spot, where exceeded 1 trillion CNY in 2017, whereas BOC's green credit ratio is at the top spot, where it reached $12.44 \%$.

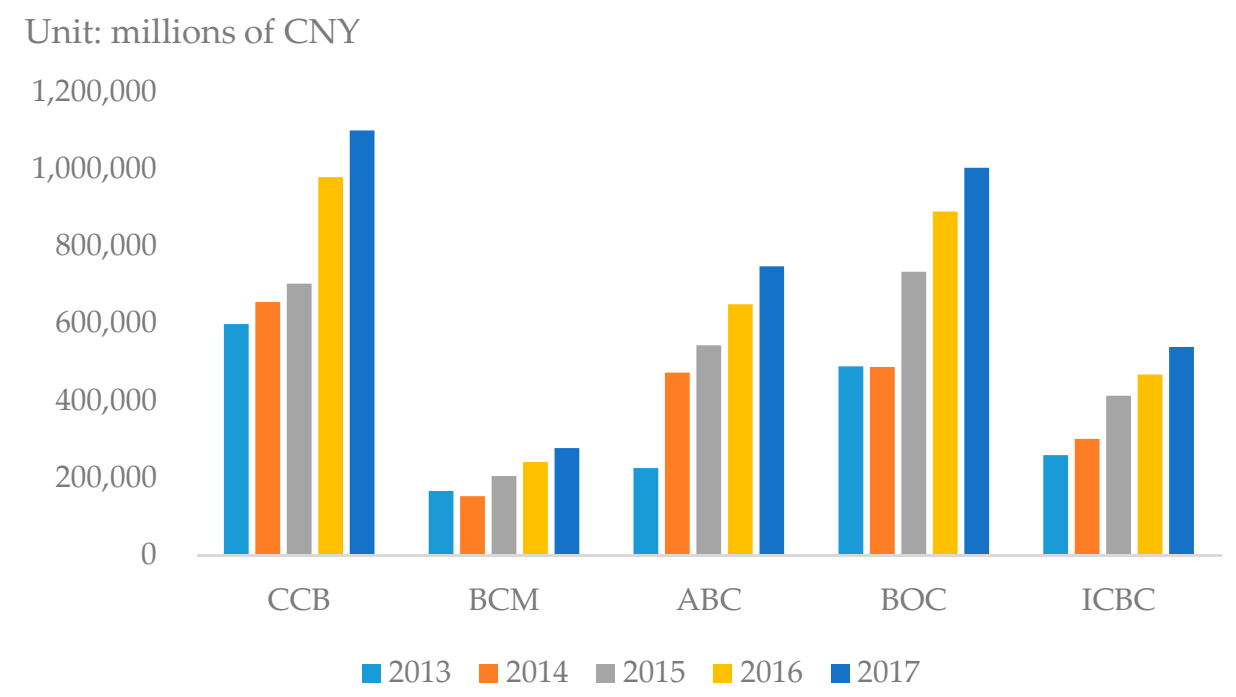

Figure 1. China five largest state-owned commercial banks' (SOCBs) green credit balance for 2013-2017.

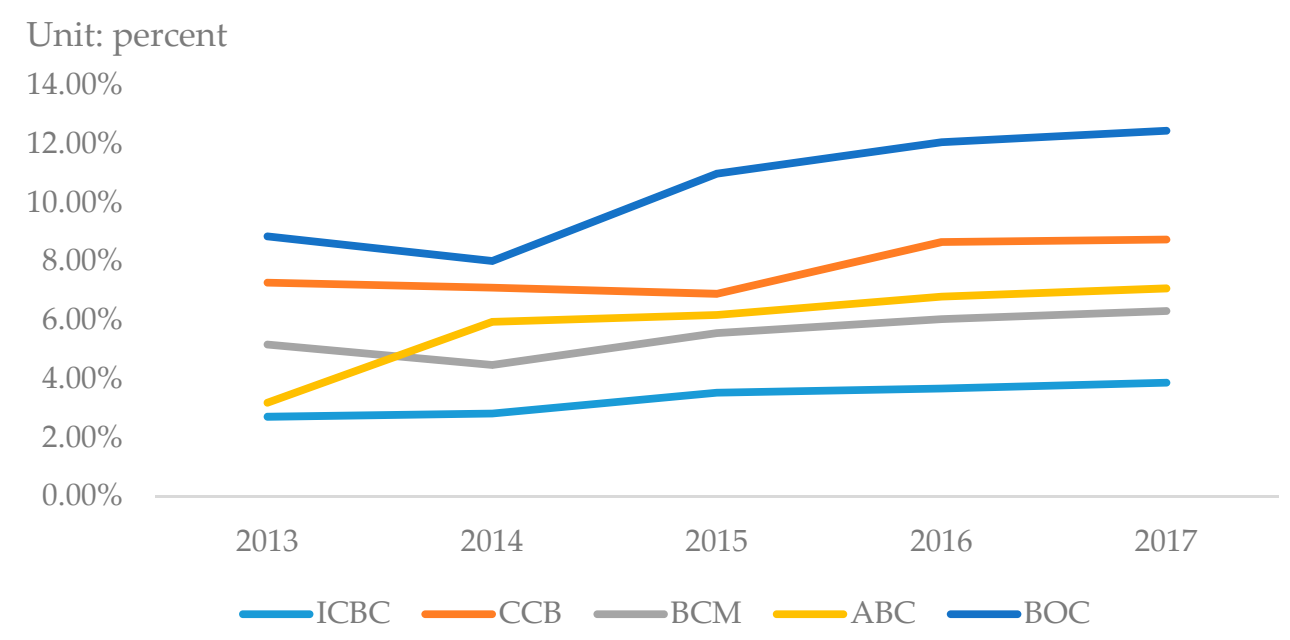

Figure 2. China five largest SOCBs' green credit ratio for 2013-2017.

Romer (1990) [2] and Furman and Hayes (2004) [3] believed that R\&D activities are a continuous driving force for national scientific and technological progress, which can promote the sustained growth of the national economy. From a micro perspective, companies' R\&D activities can create and accumulate knowledge. Therefore, it is an important force that cannot be ignored in strengthening the country's independent innovation capability and promoting economic development. The main purpose of the green financial system is to increase capital in the green industry. Green credit provides loans to environmental protection companies, and guides the transfer of credit funds to green industries. In addition, it provides necessary financial support for environmental protection companies to carry out R\&D progress, and promotes the sustainable development of social economy. However, most of the existing research focuses on the effect of green credit on the competitiveness of banks, whereas few studies investigate the effect of green credit on companies. This study believes that environmental protection companies are the main targets for banks to issue green credit, while they are the mainstay of environmental pollution control. The R\&D of environmental protection companies can promote the invention of green products and innovation of environmental protection processes. It can also 
improve the competitiveness of companies and provide continuous support and motivation for the healthy development of the green economy. Therefore, this study intends to investigate the positive but nonlinear effect of green credit on $R \& D$ levels from the perspective of environmental protection companies.

The rest of this paper is structured as follows: Section 2 presents the literature review. Section 3 analyzes the threshold mechanisms, clarifies the effect of firm size, bank lending, and government subsidies on the threshold effect of green credit on the R\&D level, and proposes three hypotheses accordingly. Section 4 introduces the variable selection and panel threshold model. Section 5 conducts an empirical study to confirm the three proposed hypotheses. Section 6 concludes and provides recommendations.

\section{Literature Review}

As a type of "sustainable finance" (Wright (2012) [4]), green credit provides credit support and preferential low interest rates for enterprises. According to the environmental and industrial economic policies, the green credit tool contributes to green environmental protection, thereby realizing the green allocation of funds and achieving the objective of protecting the environment (Zhou et al. (2015) [5]). Throughout the existing literature, local and international scholars paid more attention to the definition and development of green credit (i.e., Chen (2010) [6]), and relationship between financial development and technological progress (i.e., Jeucen (2010) [7]). Shao et al. (2015) [8] used the generalized method of moments (GMM) to examine the panel data of 29 provinces in China from the perspective of financial depth and width. In the early stage of technological innovation, the role of financial width in technological innovation is considered stimulating; however, in the advanced stage, the role of financial depth becomes clear. Zhao (2016) [9] used the effect regression model to study the panel data of 31 provinces in China. He explored the positive effect of financial development on regional innovation output from the perspective of financial intermediation and credit market development. Among them, promoting financial intermediation in regional innovation is more meaningful than promoting the development of the stock market. Law et al. (2018) [10] used GMM to study the panel data of 75 developed and developing countries and argued that a nonlinear relationship exists between financial development and innovation. Financial development has promoted innovation to a certain extent, and good institutional quality is a prerequisite for financial development to be conducive to innovation.

As the economy develops, countries are gradually recognizing the importance of protecting the environment. Scholars also recognized that banks are an important and successful part of the path to sustainable development (Emtairah et al. (2006) [11]; Zhang et al. (2011) [12]). Bouma et al. (2017) [13] argued that sustainable banking supports the development of green financing from two sources, namely, supporting the development of proactive innovation companies and stimulating the lagging and reactive ones to reform and innovate. The green credit policy introduces the concept of environmental protection to bank credit, which can not only achieve the aim of protecting the environment and promoting the coordinated development, but also enhance the competitiveness of banks. Although environmental problems bring significant credit risks to banks, corporate investment in environmental technologies and pollution control measures has also provided banks with lucrative lending opportunities (Thompson (1998) [14]). Therefore, the current research is mainly viewed from the perspective of banks, generally believing that green credit can improve the competitiveness of banks. Schaltegger and Figge (2000) [15] and Repetto and Austin (2000) [16] corroborated the companies that strengthen environmental management and governance investment will not only considerably affect corporate financial performance, but also increase the business performance of financial institutions. Thompson and Cowton (2004) [17] sent a questionnaire to lending banks in the UK and affirmed that the majority are willing to incorporate environmental considerations into their standard processes for loan issuance and investment strategies. At the same time, the banks attached notable importance to obtaining relevant and reliable environmental information about 
loan companies. Cilliers et al. (2010) [18] posited that the green credit tool can create economic spin-offs, which effectively improves the performance of commercial banks and promotes sustainable development. Hu and Cao (2011) [19] summarized the practice of green credit in Chinese commercial banks. They contended that the development of green credit has a positive guiding effect on commercial banking business transformation and credit structure adjustment, but there is still a need to further strengthen environmental risk management. Ma and Liu (2013) [20], Weng et al. (2015) [21], and Jiang and $\mathrm{Xu}$ (2016) [22] summarized the practical cases of developing green credit business in commercial banks in developed countries (such as the United States, The Netherlands, and Japan). They put forward that commercial banks should work with governments and green companies to build a healthy green financial system. This will strengthen the management capabilities of various types of risks, thereby improving the bank's comprehensive competitiveness. Gao and Gao (2018) [23] based their study on 20 banks in China and argued that green credit has a positive effect on the competitiveness of commercial banks. Cui et al. (2018) [24] used the panel regression model to analyze 24 Chinese banks and investigated the Chinese green credit policy from a credit risk perspective. The authors validated that green credit can reduce banks' nonperforming loan ratio and has a significant positive impact on the environmental and financial performance of banks.

Another important purpose of the country to develop green credit is to effectively promote energy saving and emissions reduction, protect the environment, and avoid environmental risks. Banks mainly target the issuance of green credit to companies, which are the mainstay of green credit gains and main producers of environmental pollution. Therefore, environmental protection companies should assume more social and environmental responsibility. Aupperle et al. (1985) [25] argued the companies that actively undertake social responsibility have a significant competitive advantage over other nonresponsible companies. Russo and Fouts (1997) [26], Margolis et al. (2009) [27] verified that undertaking social responsibility has a significant positive impact on a company's financial performance. In addition, fulfilling social responsibilities, such as environmental protection, has the greatest impact on the financial performance of the enterprise. That is, the environmental performance of the companies is positively correlated with economic performance. Thus, from the perspective of the company, exploring whether green credit can influence R\&D level to achieve the task of protecting environment is innovative and important. Therefore, this study uses the panel threshold model to empirically investigate the impact of green credit on R\&D level from the perspective of companies, thus further promoting the development of green financing in China.

\section{Theoretical Analysis of Threshold Effect}

Environmental protection companies use green credit for the technology investments. Although the economic benefits may not be inflected in the current period, it will be improved in the long run. Because of this characteristic, companies with small firm size, less bank lending, and less government subsidies will not fully use green credit to improve their R\&D level. Therefore, the positive effect between green credit and company $R \& D$ level is weak. On the contrary, this positive effect will increase. Therefore, the effect of green credit on the R\&D level of environmental protection companies may be nonlinear. That is to say, the degree of influence may change after certain important variables reach a certain level. The panel threshold model is a nonlinear econometric model. In essence, it incorporates the threshold value into an empirical model as an unknown variable and constructs a piecewise function of the regression coefficient of the independent variable. It aims to estimate the threshold value endogenously and estimate the parameters for different threshold regions. This study introduces the panel threshold model to the research on the effect of green credit on the R\&D level. Furthermore, it takes the levels of firm size, bank lending, and government subsidies as threshold variables. According to economic theory and classical literature, the reasons and theoretical mechanisms of the threshold effect are as follows. 


\subsection{Firm Size}

Research on firm size and company R\&D innovation begins with the "Schumpeter hypothesis". Schumpeter believed that large companies can afford expensive R\&D innovation costs and absorb failures through a wide range of R\&D innovations. Compared with small companies, large-scale companies have lower production cost and more significant combined effect. Large-scale environmental protection companies have more abundant financial resources and stronger market competitiveness and market control. In addition, large-scale environmental protection companies have a better atmosphere for innovation, which can attract more high-tech talent, and they also have stronger ability to develop new green products. Therefore, when large-scale companies receive green credit, they also invest more in R\&D activities.

The R\&D innovation of environmental protection companies require a large amount of capital investment in the early stage. However, the $R \& D$ of green products and environmental protection technologies have high risks with huge uncertainty. Smaller environmental companies are unable to withstand the pressure of high costs due to high investment, high failure rate, and uncertain recovery characteristics. Even with green credit, making new innovations remains difficult. Asidharan et al. (2015) [28] posited that small and medium enterprises (SMEs) face further financing constraints, in other words, SMEs only rely on increasing registered capital as a source of funding for $R \& D$ investment. On one hand, high output rates, abundant human resources, and good financing channels guarantee the success of R\&D activities for large-scale companies (Zou et al. (2015) [29]). On the other hand, the investment of large companies is diverse, which can reduce risks and conducive to R\&D activities. Therefore, after receiving green credit, large-scale environmental protection companies are more enthusiastic about green innovation. Thus, this study proposes the following.

Hypothesis 1. Firm size can affect the relationship between green credit and company RED level.

\subsection{Bank Lending}

In countries with a high level of financial development, the level of marketization of banks is also relatively high. Banks frequently provide a large amount of credit lines to compete for company customers. Enterprises can also adjust their loans within the bank's credit line according to their business conditions and thus obtain a flexible and convenient source of funds. The R\&D level of environmental protection companies is characterized by high risk, long incubation period, and lag of revenue. Therefore, companies should provide stable and sustained financial support for R\&D innovation. However, accurately observing the real risks and values of R\&D innovation of environmental protection companies is difficult for banks, which will result in "the Market for Lemons" (Brealey et al. (1977) [30]).

In addition, research has confirmed that company R\&D innovation allocates the majority of their budget on the salary of R\&D staff (Hall and Lerner (2010) [31]). In the long R\&D cycle, environmental protection companies should invest a large amount of money in employee wages to ensure the smooth progress of innovation activities. This prerogative requires environmental companies to secure adequate, sustained, and stable funding to support green R\&D innovation. Therefore, environmental protection companies with low bank lending level have insufficient funds to support R\&D activities, and the cost of conducting R\&D activities is high. These companies have low enthusiasm for R\&D innovation after obtaining green credit and they are reluctant to further carry out R\&D activities. By contrast, environmental protection companies with a high bank lending level have lower costs for R\&D activities. After obtaining green credit, these companies will be increasingly willing to increase R\&D investment and are motivated to carry out R\&D activities. Moreover, environmental protection companies with high enthusiasm for $R \& D$ innovation will receive extra green credit, which will further stimulate the R\&D investment. Thus, this study proposes the following.

Hypothesis 2. Bank lending can affect the relationship between green credit and company RED level. 


\subsection{Government Subsidies}

Environmental protection companies have high R\&D innovation costs. Therefore, governments of all countries should subsidize the R\&D innovation through direct subsidies, tax incentives, or loans to stimulate enthusiasm for innovation and improve the R\&D level. With the development of government subsidies, scholars from various countries studied the effects of government subsidies. Heshmati and Loof (2005) [32], Hewitt and Roper (2010) [33] argued that government subsidies have an incentive effect on R\&D innovation of enterprises. That is to say, as the amount of government subsidies increases, the R\&D level of enterprises also improves. However, Wallsten (2000) [34] and Becker (2015) [35] argued that government subsidies have a substitution effect on R\&D innovation of enterprises. Namely, as the amount of government subsidies increases, the R\&D level of enterprises decreases.

Environmental protection companies may experience market failures in R\&D innovation. The social benefits of R\&D innovation investment are greater than private income. As such, environmental protection companies cannot optimize all the benefits from R\&D activities after obtaining green credit from banks. Hence, the innovation enthusiasm of environmental protection enterprises is low. Government subsidies can correct market failures and narrow the gap between social benefits and personal incomes of $R \& D$ activities. Therefore, companies with more government subsidies can better mitigate this situation and thus improve the R\&D level of enterprises.

Second, asymmetric information exists in the R\&D of environmental protection companies. The high degree of asymmetric information between green credit providers and enterprises is likely to lead to adverse selection, which increases financing costs and generates financing constraints. In addition to providing funds for environmental protection companies, government subsidies also have a certain signal transmission function. To a certain extent, the increase in government subsidies can also provide green credit providers with a signal on the quality of $R \& D$ activities. Thus, companies with more government subsidies can further narrow the information gap between environmental protection companies and green credit providers, and further reduce information asymmetry. Thus, this study proposes the following.

Hypothesis 3. Government subsidies can affect the relationship between green credit and company RED level.

\section{Selecting Variables and Building Models}

This paper focuses on the positive but nonlinear effect of green credit on the R\&D level of environmental protection companies and studies the heterogeneity under different levels of firm size, bank lending, and government subsidies. To avoid the impact of extreme values on the research results, we exclude companies with missing financial data and companies that are being traded or have been traded special treatment (ST) by the Shanghai and Shenzhen Stock Exchanges. Finally, we select the annual data of 24 environmental protection companies that are listed on the A-share market as panel data samples for 2012-2017, and obtain a total of 144 valid samples. All data are derived from CSMAR and annual reports of environmental protection companies. Data processing uses STATA. Each variable is defined as follows.

Dependent variable: The R\&D level of environmental protection companies (R\&D, unit: CNY). The R\&D innovation of environmental protection companies mainly includes two aspects, namely, $R \& D$ investment and output. $R \& D$ investment can reflect the company's scientific and technological strength and core competitiveness, which are mainly measured by R\&D expenditure. R\&D output is mainly measured by the number of patents of enterprises. Based on the availability of data, we use the $R \& D$ expenditure to measure the $R \& D$ level of environmental companies.

Independent variable: green credit (green, unit: CNY). We use the amount of new bank loans of the current year from environmental protection companies to measure green credit.

Threshold variable: The level of firm size (size, unit: CNY). We use the logarithm of the total assets of the company to measure the level of firm size. Level of bank lending (lending, unit: CNY). We use the amount of new bank loans of the current year. (The bank lending obtained by environmental 
protection companies are almost the same as the green credit of environmental protection companies, and the independent variable can also be used as a threshold variable. Therefore, the data for the two indicators is the same, and we have named it lending for distinction.) Level of government subsidies (subsidy, unit: CNY). We use the amount of government subsidies obtained by enterprises in the current year to measure the level of government subsidies.

Controlled variable: profitability ( $\mathrm{P}$, unit: percentage). We use the total return on assets of enterprises to measure their profitability. Capital intensity (C, unit: percentage). We use the ratio of the net value of fixed assets to the total number of employees to measure capital intensity.

To reduce possible heteroscedasticity in the data of the test, the relevant variables are logarithmically used, except for those in the units of percentage (profit level and capital intensity of the enterprise). Table 1 shows the results of the statistical description of the variables.

Table 1. Statistical description of variables.

\begin{tabular}{cccccc}
\hline Variables (Unit) & Observation & Average Value & Standard Deviation & Maximum Value & Minimum Value \\
\hline R\&D (CNY) & 144 & 17.74046 & 1.327389 & 19.8821 & 13.89552 \\
Green (CNY) & 144 & 20.3845 & 1.508584 & 22.78049 & 12.83468 \\
Size (CNY) & 144 & 22.47814 & 0.823423 & 24.28188 & 20.39438 \\
Lending (CNY) & 144 & 20.3845 & 1.508584 & 22.78049 & 12.83468 \\
Subsidy (CNY) & 144 & 16.3441 & 1.599552 & 20.34068 & 10.81978 \\
P (\%) & 144 & 0.059484 & 0.028609 & 0.153079 & -0.075948 \\
C (\%) & 144 & 12.713 & 1.074229 & 15.06218 & 9.511347 \\
\hline
\end{tabular}

Tong and Lim (1980) [36] first proposed the threshold autoregressive model and applied it to time-series analysis, but the threshold regions of the model were artificially set and lacked reliability. Hansen (1999) [37] proposed the static panel threshold model and extended it to the level of panel data. The model is used to analyze the influence of the threshold variables on the independent variables when they are at different regions, thereby reflecting the nonlinear influence of the independent variables on the dependent variables. The threshold value and number are completely and endogenously determined by the sample data, which effectively avoids the deviation caused by artificially dividing the sample regions. The model also provides a confidence interval for the parameters to be estimated, and the F statistic and bootstrap methods can be used to estimate the significance of the threshold value. The basic model for constructing an empirical analysis is as follows:

$$
Y_{i t}=\left\{\begin{array}{l}
\mu_{i}+\beta_{0}^{\prime} z_{i t}+\beta_{1}^{\prime} x_{i t}+e_{i t}, q_{i t} \leq \gamma \\
\mu_{i}+\beta_{0}^{\prime} z_{i t}+\beta_{2}^{\prime} x_{i t}+e_{i t}, q_{i t}>\gamma
\end{array}\right.
$$

where $i$ represents environmental protection companies; $t$ denotes the year; $Y_{i t}$ pertains to the dependent variable, which indicates the R\&D level; $x_{i t}$ refers to the independent variable, which indicates the level of green credit; $q_{i t}$ represents the threshold variable; $\gamma$ stands for the threshold value to be estimated; $e_{i t}$ denotes a random disturbance item; $\mu_{i t}$ is used to remove individual-specific means; $\beta_{0}^{\prime}, \beta_{1}^{\prime}$, and $\beta_{2}^{\prime}$ represent the coefficients to be estimated for each variable; $z_{i t}$ refers to a group of control variables that have a significant effect on R\&D level in addition to green credit; and I(.) pertains to the indicator function: when the condition in parentheses is satisfied, it is taken as 1 , otherwise, it is taken as 0 . Equation (1) can also be expressed by Equation (2) as follows:

$$
Y_{i t}=\mu_{i t}+\beta_{1}^{\prime} x_{i t} \mathrm{I}\left(q_{i t} \leq \gamma\right)+\beta_{2}^{\prime} x_{i t} \mathrm{I}\left(q_{i t}>\gamma\right)+e_{i t} .
$$

The first problem to consider is how to estimate threshold value and the slope parameters. According to Hansen's panel threshold regression model, if we aim to obtain the true threshold value $\gamma$, then we can first give an initial threshold value $\gamma_{0}$. For a given threshold value, we can 
estimate the model using the ordinary least square (OLS) regression method to obtain the sum of the squared errors:

$$
S_{1}\left(\gamma_{0}\right)=\hat{e}^{*}(\gamma) \hat{e}^{*}(\gamma)=Y^{* \prime}\left(1-x^{*}(\gamma) \prime\left(x^{*}(\gamma) \prime x^{*}(\gamma)\right)^{-1} x^{*}(\gamma)\right) Y^{*}
$$

where $Y_{i t}^{*}=Y_{i t}-\bar{Y}_{i t}, x_{i t}^{*}=x_{i t}-\bar{x}_{i t}, e_{i t}^{*}=e_{i t}-\bar{e}_{i t}$.

According to Chan (1993) [38], when the sum of the squared errors $S_{1}\left(\gamma_{0}\right)$ is smaller, the given threshold value $\gamma_{0}$ is closer to the true threshold value $\gamma$. Therefore, we obtain the threshold estimated value by minimizing the sum of squared errors $S_{1}\left(\gamma_{0}\right)$. The least squares estimators are as follows:

$$
\hat{\gamma}=\underset{\gamma}{\operatorname{argmin}} S_{1}\left(\gamma_{0}\right)
$$

The residual variance is as follows:

$$
\hat{\sigma}^{2}=\frac{1}{n(T-1)} \hat{e}^{* \prime} \hat{e}^{*}=\frac{1}{n(T-1)} S_{1}(\hat{\gamma}) .
$$

Although we assume that there is a threshold effect, whether it is statistically significant requires further testing. The hypothesis of no threshold effect in (1) can be represented by the linear constraint $H_{0}: \beta_{1}=\beta_{2}$.

Hansen (1996) [39] suggested a bootstrap to simulate the asymptotic distribution of the likelihood ratio test. The bootstrap procedure attains the first-order asymptotic distribution, so $p$-values constructed from the bootstrap are asymptotically valid. Thus, we can get the bootstrap estimate of the asymptotic $p$-value for $F_{1}$ under $H_{0}$ (where $\left.F_{1}=\left(S_{0}-S_{1}(\hat{\gamma})\right) / \hat{\sigma}^{2}\right)$. The null of no threshold effect is rejected if the $p$-value is smaller than the desired critical value.

After testing the threshold effect, the next problem is to establish the asymptotic distribution of threshold estimate. Hansen (1999) argues that the best way to form confidence intervals for $\gamma$ is to form the "no-rejection region" using the likelihood ratio statistic for tests on $\gamma$. It is pivotal to form valid asymptotic confidence intervals. Hansen then derives the distribution function to calculate particular values easily.

The final problem is to establish the asymptotic distribution of slope coefficients. The estimator $\hat{\beta}=\hat{\beta}(\hat{\gamma})$ depends on the threshold estimate $\hat{\gamma}$. Hansen (1999) shows that the dependence on the threshold estimate is not of first-order asymptotic importance, so inference on $\beta$ can proceed as if the threshold estimate $\hat{\gamma}$ were the true value.

Model (1) has a single threshold. In some applications there may be multiple thresholds. For example, the double threshold model takes the form

$$
Y_{i t}=\mu_{i}+\beta_{0}^{\prime} z_{i t}+\beta_{1}^{\prime} x_{i t} I\left(q_{i t} \leq \gamma_{1}\right)+\beta_{2}^{\prime} x_{i t} I\left(\gamma_{1}<q_{i t} \leq \gamma_{2}\right)+\beta_{3}^{\prime} x_{i t} I\left(q_{i t}>\gamma_{2}\right)+e_{i t} .
$$

This study will build the panel threshold model on the basis of the preceding variables. $q_{i t}$ represents the threshold variable, which is brought into firm size, bank lending, and government subsidies. The single threshold model can be expressed as follows:

$$
Y_{i t}=\mu_{i}+\beta_{0}^{\prime} z_{i t}+\beta_{1}^{\prime} \text { green }_{i t} I\left(q_{i t} \leq \gamma\right)+\beta_{2}^{\prime} \text { green }_{i t} I\left(q_{i t}>\gamma\right)+e_{i t} .
$$

The double threshold model can be extended on the basis of Equation (7):

$$
Y_{i t}=\mu_{i}+\beta_{0}^{\prime} z_{i t}+\beta_{1}^{\prime} \text { green }_{i t} I\left(q_{i t} \leq \gamma_{1}\right)+\beta_{2}^{\prime} \text { green }_{i t} I\left(\gamma_{1}<q_{i t} \leq \gamma_{2}\right)+\beta_{3}^{\prime} \text { green }_{i t} I\left(q_{i t}>\gamma_{2}\right)+e_{i t} .
$$

\section{Empirical Results and Analysis}

The estimation of the panel threshold model first sets the core independent variables. This study investigates the nonlinear effect of green credit on the R\&D level of environmental protection 
companies under different levels of firm size, bank lending, and government subsidies. Therefore, this study sets up the level of green credit as the core independent variable. Based on the matrix of correlations, the variance inflation factor test and the regressor endogeneity test results, we verify that there are no severe multicollinearity and endogeneity problems. Afterward, this study uses the self-sampling method to repeatedly sample 300 times for simulation, and utilizes the point search method to determine the threshold number of the model. Table 2 provides the specific $f$ and $p$ values. The table shows that under the double threshold model, when the levels of firm size, bank lending, and government subsidies are used as threshold variables, the $p$ values reject the null hypothesis at the $95 \%$ significance level.

Table 2. Double threshold effect test.

\begin{tabular}{ccccccc}
\hline Variables & $f$ Value & $p$ Value & BS & $\mathbf{1 0 \%}$ & $\mathbf{5 \%}$ & $\mathbf{1 \%}$ \\
\hline Size & 54.53 & 0.0000 & 300 & 14.9447 & 19.1788 & 27.5368 \\
Lending & 15.40 & 0.0367 & 300 & 12.1916 & 14.1570 & 17.7768 \\
Subsidy & 16.90 & 0.0100 & 300 & 10.1553 & 12.0906 & 16.1619 \\
\hline
\end{tabular}

Table 3 shows that green credit has different threshold effects on the R\&D level of environmental protection companies. When the levels of firm size, bank lending, and government subsidies are used as threshold variables, double threshold values, namely, 19.9682 and 21.6431, 21.7710 and 22.8814, and 14.4139 and 14.581 , respectively, occur.

Table 3. Threshold value estimates.

\begin{tabular}{ccc}
\hline Variables & Threshold Value $\mathbf{1}$ [Lower Upper] & Threshold Value 2 [Lower Upper] \\
\hline Size & $19.9682[19.895119 .9928]$ & $21.6431[21.575521 .6619]$ \\
Lending & $21.7710[21.676021 .7811]$ & $22.8814[22.800622 .8863]$ \\
Subsidy & $14.4139[14.134514 .4228]$ & $14.5981[14.422814 .6994]$ \\
\hline
\end{tabular}

Table 4 shows the threshold model regression results when the levels of size firm, bank lending, and government subsidies are used as threshold variables. When the threshold variables differ, the effect of green credit on the R\&D level of environmental protection companies also differs. When the same threshold variable is in different threshold regions, the effect of green credit on the R\&D level of environmental protection companies also changes.

Table 4. Threshold model regression results.

\begin{tabular}{cccc}
\hline \multirow{2}{*}{ R\&D } & \multicolumn{3}{c}{ Threshold Effect Model } \\
\cline { 2 - 4 } & Size & Lending & Subsidy \\
\hline \multirow{2}{*}{ Green } & $0.0562938(0.192)$ & $0.0939122(0.141)$ & $0.2886952^{* * *}(0.000)$ \\
& $($ size $\leq 19.9682)$ & $($ credit $\leq 21.7710)$ & $($ subsidy $\leq 14.4139)$ \\
& $0.1023458^{* * *}(0.010)$ & $0.1267195^{* * *}(0.028)$ & $0.3702444^{* * *}(0.000)$ \\
& $(19.9682<$ size $\leq 21.6431)$ & $(21.7710<$ credit $\leq 22.8814)$ & $(14.4139<$ subsidy $\leq 14.5981)$ \\
P & $0.1363294^{* * *}(0.001)$ & $0.1616295^{* * *}(0.004)$ & $0.2944418^{* * *}(0.000)$ \\
C & $($ size $>21.6431)$ & $($ credit $>22.8814)$ & $($ subsidy $>14.5981)$ \\
Cons & $7.025448^{* * *}(0.000)$ & $6.780357^{* * *}(0.001)$ & $5.544738^{* * *}(0.010)$ \\
obs & $0.0741786(0.354)$ & $0.1009446(0.300)$ & $0.079902(0.443)$ \\
$f$ test & $14.22929^{* * *}(0.000)$ & $13.52915^{* * *}(0.000)$ & $10.39356^{* * *}(0.000)$ \\
Prob $>f$ & 144 & 144 & 144 \\
\hline
\end{tabular}

Note: () is the standard error, ${ }^{\prime * * * * \prime}$ represent $1 \%$ levels of significance. 
(1) Using the level of firm size as a threshold value. When the level of firm size is lower than the first threshold value (size $=19.9682$ ), green credit has no significant positive effect on the R\&D level of the environmental protection companies, where the marginal coefficient of the effect is 0.0562938 . When the level of firm size is higher than the first threshold value but lower than the second threshold value (size $=21.6431$ ), green credit has a significant positive effect on the R\&D level of environmental protection companies, where the marginal coefficient of the effect is 0.1023458 . When the level of firm size is higher than the second threshold value, the significant positive effect is deepened, where the marginal coefficient of the effect is 0.1363294 . Table 4 shows that green credit has a positive but nonlinear effect on the R\&D level of environmental protection companies. When the level of firm size is high, green credit has a large positive effect on the R\&D level; when the level of firm size is low, the positive effect is small. Therefore, large-scale environmental protection companies can further use green credit to improve R\&D levels, which confirms Hypothesis 1. The findings corroborate that the positive effect of green credit on R\&D of environmental protection companies is affected by the level of firm size. Larger-scale companies have higher level of technology and stronger market control. Hence, the cost of R\&D innovation is lower, and R\&D activities are more frequent.

(2) Using the level of bank lending as a threshold value. When the level of bank lending is lower than the first threshold value (lending $=21.7710$ ), green credit has no significant positive effect on the R\&D level of environmental protection companies, where the marginal coefficient of the effect is 0.0939122 . When the level of bank lending is higher than the first threshold value but lower than the second threshold value (lending $=22.8814$ ), green credit has a significant positive effect on the R\&D level of environmental protection companies, where the marginal coefficient of the effect is 0.1267195 . When the level of bank lending is higher than the second threshold value, the significant positive effect is deepened, where the marginal coefficient of the effect is 0.1616295 . Table 4 shows that green credit has a positive but nonlinear effect on the R\&D level of environmental protection companies. When the level of bank lending is high, green credit has a large positive effect on the R\&D level; when the level of bank lending is low, the positive effect is small. Therefore, environmental protection companies with larger bank lending can further use green credit to improve R\&D levels, which confirms Hypothesis 2. Results prove that the positive effect of green credit on R\&D innovation of environmental protection companies is affected by bank lending. When companies receive additional sustained and stable financial support from banks, they will have increased enthusiasm for R\&D activities and green product innovation.

(3) Using the level of government subsidies as a threshold variable. When the level of government subsidies is lower than the first threshold value (subsidy $=14.4139$ ), green credit has a significant positive effect on the R\&D level of environmental protection companies, where the marginal coefficient of the effect is 0.2886952 . When the level of government subsidies is higher than the first threshold value but lower than the second threshold value (subsidy $=14.591$ ), the positive effect is deepened, where the marginal coefficient of the effect is 0.3702444 . However, when the level of government subsidies is higher than the second threshold value, the significant positive impact is weakened, where the marginal coefficient of the effect is 0.2944418 . Table 4 shows that green credit has a positive but nonlinear effect on the R\&D level of environmental protection companies. When the level of government subsidy is high, green credit has a large positive effect on the R\&D level; when the level of government subsidy is low, the positive effect is small. That is, environmental protection companies with more government subsidies can further use green credit to improve their R\&D level, which confirms Hypothesis 3. Enterprises with further government subsidies have improved market failures and asymmetry information, reduced R\&D innovation costs, and increased positive effect on R\&D innovation after obtaining green credit. However, excessive government subsidies bring problems, such as rising market resources and inadequate supervision, which result in the abuse of subsidies. Therefore, when the government 
subsidizes environmental protection companies, it must find an effective range of government subsidies to achieve the potential of the policy.

\section{Conclusions and Recommendations}

This study uses panel data for 24 environmental protection companies in China over 2012-2017 to test the effect of China's green credit on R\&D level. The empirical results verify the three hypotheses proposed in this paper, which confirm that green credit has a positive but nonlinear effect on the R\&D level of environmental protection companies. Furthermore, green credit is influenced by the levels of firm size, bank lending, and government subsidies. We draw the following conclusions.

(1) When the level of firm size is below 19.9682, green credit has no significant positive effect on the R\&D level of environmental protection companies. When the level of firm size is higher than 19.9682 but lower than 21.6431, green credit has a significant positive effect on the R\&D level. When the level of firm size is higher than 21.6431, the significant positive effect is deepened.

(2) When the level of bank lending is below 21.7710, green credit has no significant positive effect on the R\&D level of environmental protection companies. When the level of bank lending is higher than 21.7710 but lower than 22.8814, green credit has a significant positive effect on the R\&D level. When the level of bank lending is higher than 22.8814 , the significant positive effect is deepened.

(3) When the level of government subsidies is below 14.4139, green credit has a significant positive effect on the R\&D level of environmental protection companies. When the level of government subsidies is higher than 14.4339 but lower than 14.5981, the positive effect is deepened. However, when the level of government subsidies is higher than 14.59, the significant positive effect is weakened.

Developing green credit and promoting R\&D innovation of environmental protection companies require the joint efforts of the government, commercial banks, and regulatory authorities. Thus, this collaboration can create a good social and financial environment in which to promote sustainable economic development. Therefore, in combination with the above-mentioned conclusions, we propose the following suggestions.

(1) Banks should formulate green credit policy based on the characteristics of company heterogeneity. The R\&D innovation of environmental protection companies requires banks to provide a large amount of green financing. The country's green development and transformation also require a large amount of financial support. Banks should formulate reasonable and effective mechanisms to invest more funds in green and sustainable development. This study finds that green credit has a positive but nonlinear effect on $R \& D$ level of environmental protection companies. Therefore, when formulating green credit policies, the heterogeneity of environmental protection companies should be fully considered. Large-scale environmental protection companies can further use green credit to improve the R\&D level; hence, banks should increase green credit for large-scale companies. Companies with larger bank lending can further use green credit to improve their R\&D level. Therefore, green credit should be added to companies with large bank lending. Companies that have more government subsidies can further use green credit to improve their R\&D level. Therefore, green credit should be added to companies with more government subsidies.

(2) According to the Schumpeter hypothesis, smaller companies are expensive to develop, and face high financing constraints. Therefore, smaller environmental protection companies cannot fully utilize green innovation when they receive green credit. Environmental protection companies with low bank lending level have insufficient stable funds to support R\&D activities, and R\&D costs are high. Therefore, companies with low bank lending level cannot fully utilize green innovation when they obtain green credit. Government subsidies can correct market failure and serve as a signal to reduce the adverse selection problems caused by high asymmetry 
information. Therefore, when government subsidies are small, the companies cannot fully utilize green innovation when they obtain green credit. Therefore, when formulating green credit policy, banks should limit the green credit use of environmental protection companies, specifically enterprises with smaller firm size, lower bank lending, and less government subsidies. Furthermore, the supervision of the use of green credit should be strengthened.

(3) Strengthen the role of the government in sustainable development and promote innovation in green financial products. While providing subsidies for environmental protection companies, the government should consider the scope of government subsidies. The government should determine the optimal subsidy interval based on the evaluation results of different enterprise R\&D innovation projects. Thereby, promote the smooth transformation of government subsidies into the R\&D incentives of environmental protection companies, and ensure that the limited funds are used to maximum effectiveness. The government can also formulate preferential policies to encourage banks and financial institutions to implement green credit and promote the green development of environmental protection companies. Moreover, the government should encourage companies to carry out green innovation, introduce high-tech talent, and improve production technology. According to the Porter hypothesis, green innovation can enhance the competitiveness of enterprises, thereby offsetting the cost of environmental protection and promoting high-quality economic growth. Although the benefits of innovation may not be reflected in the current period, it may improve the company's revenue and achieve sustainable development in the long run.

Author Contributions: Conceptualization, H.C., C.L. and F.X.; Data curation, H.C.; Formal analysis, H.C.; Funding acquisition, C.L.; Investigation, H.C.; Methodology, H.C.; Resources, H.C. and C.L.; Software, H.C.; Supervision, C.L.; Validation, H.C.; Visualization, F.X. and T.Z.; Writing, original draft, H.C.; Writing, review, and editing, H.C., C.L., F.X., T.Z., and F.G.

Funding: This research was funded by the "Double-First Class" Think Tank Program of China University of Mining and Technology (Grant No. 2018WHCC01).

Acknowledgments: The authors are grateful for the financial support provided by the "Double-First Class" Think Tank Program of China University of Mining and Technology (No.2018WHCC01).

Conflicts of Interest: The authors declare no conflict of interest. The funders had no role in the design of the study; collection, analyses, or interpretation of data; writing of the manuscript; and decision to publish the results.

\section{References}

1. Aizawa, M.; Yang, C. Green credit, green stimulus, green revolution? China's mobilization of banks for environmental cleanup. J. Environ. Dev. 2010, 19, 119-144. [CrossRef]

2. Romer, P.M. Endogenous technological change. J. Political Econ. 1990, 98, S71-S102. [CrossRef]

3. Furman, J.L.; Hayes, R. Catching up or standing still? National innovative productivity among follower countries, 1978-1999. Res. Policy 2004, 33, 1329-1354. [CrossRef]

4. Wright, C. Global banks, the environment, and human rights: The impact of the Equator Principles on lending policies and practices. Glob. Environ. Politics 2012, 12, 56-77. [CrossRef]

5. Zhou, Y.S.; Liu, Q.R.; Li, J.; Zhao, Y.X. Game model for governments to promote banks as the agency to supervise the implementation of green supply chain based on green credit. Syst. Eng. Theory Pract. 2015, 35, 1744-1751.

6. Chen, L.Q. Dynamic analysis of green credit development at home and abroad. Glob. Sci. Technol. Econ. Outlook 2010, 6, 45-56.

7. Jeucken, M. Sustainable Finance and Banking: The Financial Sector and the Future of the Planet; Routledge: London, UK, 2010.

8. Shao, Y.H.; Liu, S.B.; Zhang, C.Y. Financial development model and economic growth under the difference of innovation: Theory and evidence. Manag. World 2015, 11, 29-39.

9. Zhao, W. Financial development and regional innovation output growth: Based on empirical analysis of provincial panel data in China. Mod. Econ. 2016, 7, 10. [CrossRef] 
10. Law, S.H.; Lee, W.C.; Singh, N. Revisiting the finance-innovation nexus: Evidence from a nonlinear approach. J. Innov. Knowl. 2018, 3, 143-153. [CrossRef]

11. Emtairah, T.; Hansson, L.; Hao, G. Environmental challenges and opportunities for banks in China. Greener Manag. Int. 2006, 50, 85-95. [CrossRef]

12. Zhang, B.; Yang, Y.; Bi, J. Tracking the implementation of green credit policy in China: Top-down perspective and bottom-up reform. J. Environ. Manag. 2011, 92, 1321-1327. [CrossRef]

13. Bouma, J.J.; Jeucken, M.; Klinkers, L. Sustainable Banking: The Greening of Finance; Routledge: London, UK, 2017.

14. Thompson, P. Bank lending and the environment: Policies and opportunities. Int. J. Bank Mark. 1998, 16, 243-252. [CrossRef]

15. Schaltegger, S.; Figge, F. Environmental shareholder value: Economic success with corporate environmental management. Eco-Manag. Audit. J. Corp. Environ. Manag. 2000, 7, 29-42. [CrossRef]

16. Repetto, R.; Austin, D. Pure Profit: The Financial Implications of Environmental Performance; World Resources Institute: Washington, DC, USA, 2000.

17. Thompson, P.; Cowton, C.J. Bringing the environment into bank lending: Implications for environmental reporting. Br. Account. Rev. 2004, 36, 197-218. [CrossRef]

18. Cilliers, E.J.; Diemont, E.; Stobbelaar, D.J.; Timmermans, W. Sustainable green urban planning: The Green Credit Tool. J. Place Manag. Dev. 2010, 3, 57-66. [CrossRef]

19. Hu, N.W.; Cao, D.W. Green credit policy and environmental risk management of commercial banks. Econ. Probl. 2011, 3, 026.

20. Ma, Q.J.; Liu, X. Experiences in the development of green credit business in developed countries. New Financ. 2013, 4, 57-59.

21. Weng, Z.X.; Ge, C.Z.; Duan, X.M.; Long, F. Analysis on the green financial products development and innovation in China. China Popul. Resour. Environ. 2015, 25, 17-22.

22. Jiang, X.L.; Xu, H.L. Green credit operation mechanism of commercial bank of China. China Popul. Resour. Environ. 2016, S1, 490-492.

23. Gao, X.Y.; Gao, G. A study on the relation between the scale of green credit and the competitiveness of commercial banks. Econ. Probl. 2018, 7, 003.

24. Cui, Y.; Geobey, S.; Weber, O.; Lin, H. The impact of green lending on credit risk in China. Sustainability 2018, 10, 2008. [CrossRef]

25. Aupperle, K.E.; Carroll, A.B.; Hatfield, J.D. An empirical examination of the relationship between corporate social responsibility and profitability. Acad. Manag. J. 1985, 28, 446-463.

26. Russo, M.V.; Fouts, P.A. A resource-based perspective on corporate environmental performance and profitability. Acad. Manag. J. 1997, 40, 534-559.

27. Margolis, J.D.; Elfenbein, H.A.; Walsh, J.P. Does it pay to be good... and does it matter? A meta-analysis of the relationship between corporate social and financial performance. SSRN Electron. J. 2009. [CrossRef]

28. Sasidharan, S.; Lukose, P.J.; Komera, S. Financing constraints and investments in R\&D: Evidence from Indian manufacturing firms. Q. Rev. Econ. Financ. 2015, 55, 28-39.

29. Zou, G.P.; Liu, H.D.; Wang, G.Y. Observations on the correlation between state-owned enterprises' scale and innovation intensity. Manag. Rev. 2015, 27, 171-179.

30. Brealey, R.; Leland, H.E.; Pyle, D.H. Informational asymmetries, financial structure, and financial intermediation. J. Financ. 1977, 32, 371-387. [CrossRef]

31. Hall, B.H.; Lerner, J. The Financing of R\&D and Innovation. In Handbook of the Economics of Innovation; North-Holland: Amsterdam, The Netherlands, 2010; Volume 1, pp. 609-639.

32. Heshmati, A.; Loof, H. The Impact of Public Funds on Private RED Investment: New Evidence from a Firm Level Innovation Study; Working Paper; Royal Institute of Technology: Stockholm, Sweden, 2005.

33. Hewitt-Dundas, N.; Roper, S. Output additionality of public support for innovation: Evidence for Irish manufacturing plants. Eur. Plan. Stud. 2010, 18, 107-122. [CrossRef]

34. Wallsten, S.J. The effects of government-industry R\&D programs on private R\&D: The case of the small business innovation research program. Rand J. Econ. 2000, 31, 82-100.

35. Becker, B. Public R\&D policies and private R\&D investment: A survey of the empirical evidence. J. Econ. Surv. 2015, 29, 917-942. 
36. Tong, H.; Lim, K.S. Threshold autoregression, limit cycles and cyclical data. J. R. Stat. Soc. 1980, 42, $245-292$. [CrossRef]

37. Hansen, B.E. Threshold effects in non-dynamic panels: Estimation, testing, and inference. J. Econom. 1999, 93, 345-368. [CrossRef]

38. Chan, K.S. Consistency and limiting distribution of the least squares estimator of a threshold autoregressive model. Ann. Stat. 1993, 21, 520-533. [CrossRef]

39. Hansen, B.E. Inference when a nuisance parameter is not identified under the null hypothesis. Econom. J. Econom. Soc. 1996, 64, 413-430. [CrossRef]

(C) 2019 by the authors. Licensee MDPI, Basel, Switzerland. This article is an open access article distributed under the terms and conditions of the Creative Commons Attribution (CC BY) license (http://creativecommons.org/licenses/by/4.0/). 